\title{
AS MULTIPLICIDADES IDENTITÁRIAS DE HERMIONE DA SÉRIE HARRY POTTER
}

\author{
Nincia Cecília Ribas Borges Teixeira ${ }^{1}$ \\ Amanda Padilha Pieta ${ }^{2}$
}

\begin{abstract}
Resumo: Hermione Granger é colega de turma e amiga do protagonista da série Harry Potter. A inteligência é sua principal característica e instrumento de combate contra as Artes das Trevas, mantendo-se ao lado do herói da saga nessa tarefa até o fim da aventura. A relevância da personagem para a trama é constatada em pesquisas que avaliam o favoritismo dos fãs da série, que parecem se identificar com Hermione. Este trabalho é um recorte de uma dissertação de Mestrado que investigou as possíveis representações da personagem feminina de maior destaque na série Harry Potter. O embasamento teórico dos Estudos Literários, Culturais e de Gênero conduziu a compreensão sobre como funcionam as relações entre poder e diferenciação sexual na sociedade bruxa. A identidade subversiva de Hermione desconstrói algumas matrizes culturais e nos incita a refletir sobre os estereótipos de gênero que por tanto tempo marcaram a literatura voltada para o público infantil e juvenil.
\end{abstract}

Palavras-chave: Identidade. Literatura infantojuvenil. Gênero.

\section{Embarcando na plataforma $934^{3}$}

Quem não conhece aquele bruxinho de cicatriz na testa que junto a dois amigos fizeram muitas crianças e adolescentes dos anos 2000 desejarem receber uma carta da escola de magia convidando-os a aprenderem sobre feitiços e poções? A série literária Harry Potter nasceu em 1997, na Inglaterra, por meio da escritora escocesa Joanne Kethleen Rowling, pela Editora Bloomsbury. A obra atingiu $O$ alcance global tão rapidamente que as vendas surpreenderam a cada nova edição lançada e logo um contrato para a adaptação cinematográfica da saga foi oferecido pela Warner Brothers que lançou o primeiro filme em 2001, aumentando ainda mais a projeção mundial da série.

Harry Potter é uma série literária de ficção que conta a história de um menino que, em seu aniversário de onze anos, descobre ser filho órfão de dois bruxos e, por isso, também possuir poderes mágicos. De sobrinho indesejado que morava com os tios, passa a ser um estudante de Hogwarts, uma escola inglesa

\footnotetext{
${ }^{1}$ Pós-doutora pela UFRJ. Doutora em Letras pela Universidade Estadual Paulista Júlio de Mesquita Filho (2005), Mestre em Letras pela Universidade Estadual de Londrina. É Professora Associada da Universidade Estadual do Centro-Oeste (UNICENTRO-PR).

2 Mestra em Letras pela Universidade Estadual do Centro-Oeste, UNICENTRO, Brasil.

${ }^{3} \mathrm{Na}$ versão original da obra e nos filmes a plataforma de embarque para o trem que viaja até Hogwarts fica escondida entre as plataformas nove e dez. O acesso só é permitido aos bruxos, que atravessam a coluna que separa as duas plataformas e aparecem magicamente na plataforma $93 / 4$.
}

Revista de Letras JUÇARA, Caxias - Maranhão, v. 03, n. 01, p. 122 - 141, ago. 2019 | 122 
de magia e bruxaria. Lá ele conhece os amigos Hermione Granger e Rony Weasley que embarcam com ele em diversas aventuras ao longo da série. $O$ trio tenta derrotar o temível bruxo das trevas que assassinou os pais de Harry, Lord Voldemort, cujo objetivo é liquidar o menino Potter de uma vez por todas após não ter conseguido quando ele era apenas um bebê. O vilão então passa por cima de tudo e todos no mundo da magia, com a ajuda de seus seguidores, para concretizar esse desejo maléfico.

Dez anos se passaram entre o momento em que Harry ganhou vida nas páginas dos enredos até o lançamento do sétimo e último livro, fechando a aventura. A estimativa de alcance da série é de cerca de 450 milhões de exemplares vendidos e, além disso, as adaptações da história para o cinema arrecadaram cerca de 7,7 bilhões de dólares nas bilheterias de todo o mundo. 0 público se torna imensurável se pensarmos que é quase impossível medir quantas pessoas assistiram os filmes em outros meios, como nos canais de TV, alugando em locadoras de vídeo ou pela internet; e quantas leram os livros de outra forma, seja tomando-os emprestados em bibliotecas ou de amigos.

O vasto público alcançado levou alguns estudiosos a inicialmente categorizarem a série como literatura de massa, marcada pelo seu caráter expansivo e mercadológico. A utilização de linguagem simples - próxima da fala cotidiana - foi uma característica alvo de muitos questionamentos sobre o valor literário dessa globalizada série, a partir dos critérios defendidos pelos formalistas na definição de literatura como "uma forma 'especial' de linguagem, em contraste com a linguagem 'comum'" (EAGLETON, 2006, p.7). Atualmente, com uma noção menos engessada sobre os gêneros textuais, temos consciência de que a definição de literatura é menos restrita às formas e mais relacionada aos conteúdos e às maneiras de se ler um texto, inserindo-se no contexto do leitor como "uma escrita altamente valorativa, de que ela não constitui uma entidade estável, resulta do fato de serem notoriamente variáveis os juízos de valor" (Idem, 2006, p.16-7).

Diante da complexidade em definir um conceito único de literatura infantojuvenil, tomaremos aqui a proposta dos Estudos Culturais, que norteiam esse trabalho, e segundo os quais as obras literárias atuam de maneira ativa na sociedade, como práticas culturais, pois elas podem "ser tanto uma questão daquilo que as pessoas fazem com a escrita como daquilo que a escrita faz com as 
pessoas" (EAGLETON, 2006, p.10). Considerando que "o caráter de coisa organizada da obra literária torna-se um fator que nos deixa mais capazes de ordenar nossa própria mente e sentimentos e, em consequência, mais capazes de organizar a visão que temos do mundo" (CANDIDO, 2011, p.179) e que por isso ela e outras formas de contato com produções culturais são fatores que contribuem para a formação identitária dos sujeitos, vislumbramos a obra Harry Potter por esses caminhos.

A teoria aponta que "o texto literário não mantém uma relação de referência com o 'mundo'", sendo que esse "discurso literário não pode ser verdadeiro ou falso, mas sim, não pode ser válido mais que com relação a suas próprias premissas" (TODOROV, 1998, p.14). No entanto precisamos lembrar que mesmo assim ele trará, de alguma forma, traços históricos e culturais da sociedade em seu universo fantasioso e estes serão absorvidos e interpretados pelas mentes dos leitores. Em Harry Potter, o universo mágico e o "trouxa" coexistem e apresentam algumas práticas sociais em comum. Isso faz com que o leitor perceba pontos convergentes e promova um processo identificatório com alguns temas pertinentes e presentes na intersecção entre os dois "mundos", como aponta a pesquisadora Eliane Aparecida Galvão Ribeiro Ferreira (2015):

o ficcional funciona como plausível para a narrativa ao fazer um paralelo (mas não representando tal qual) com a realidade: (...) em Hogwarts e em outros espaços sociais mágicos, existem indivíduos egocêntricos, preconceituosos e ambiciosos. Assim, pela duplicação dessa crítica nos espaços, a narrativa atua como um espelho que reflete as características presentes no individualismo da sociedade de consumo (p.113).

Uma pesquisa realizada no Reino Unido e na Itália intitulada "The greatest magic of Harry Potter: Reducing prejudice" - "A maior mágica de Harry Potter: diminuir o preconceito" em tradução livre para o português - buscou "avaliar se os romances de Harry Potter podem ser usados como ferramentas para melhorar as atitudes direcionadas a grupos estigmatizados" (VEZZALI; STATHI; GIOVANNINI; CAPOZZA; TRIFILETTI, 2015, p. 105, tradução nossa). O artigo resultado desse estudo cita algumas das práticas sociais desse universo fantástico e como elas se

\footnotetext{
4 "Trouxa" é o termo - na tradução brasileira - utilizado na série Harry Potter para designar as pessoas não dotadas de poderes mágicos. No texto original em inglês o termo é "muggle".
}

Revista de Letras JUÇARA, Caxias - Maranhão, v. 03, n. 01, p. 122 - 141, ago. 2019|124 
relacionam com temas da realidade, principalmente quanto ao preconceito direcionado a grupos marcados pela diferença:

\begin{abstract}
O mundo de Harry Potter é caracterizado por estritas hierarquias sociais e, consequentemente, por preconceitos, com paralelos evidentes com nossa sociedade. Em primeiro lugar, as pessoas sem poderes mágicos são profundamente discriminadas no "mundo mágico". Outra categoria estigmatizada é a de "meio-sangue" ou "sangue ruim", bruxos e bruxas nascidos de famílias em que apenas um dos pais tem habilidades mágicas. Outros exemplos de categorias estigmatizadas são os elfos (servos e escravos dos bruxos), os meio-gigantes (nascidos de um pai gigante e um bruxo ou bruxa "comum"), os duendes (que guardam o banco dos bruxos). Essas últimas categorias representam criaturas que não são "totalmente" humanas; elas são, no entanto, representadas por Rowling como humanizadas, e podem, assim, ser facilmente interpretadas como categorias humanas de um status inferior. Harry tem um contato significativo com personagens pertencentes a esses grupos estigmatizados. Ele tenta compreender de maneira sensível suas dificuldades, algumas das quais derivam da discriminação intergrupal, e luta por um mundo livre de desigualdades sociais (Idem, 2015, p.106, tradução nossa).
\end{abstract}

O estudo em questão entrevistou crianças, adolescentes e adultos leitores e não leitores de Harry Potter - para descobrir como se sentiam em relação a três dos grupos que mais costumam sofrer preconceito na sociedade europeia: imigrantes, refugiados e homossexuais. O resultado demonstra que a maioria dos leitores da série apresentaram respostas com noções de igualdade e respeito sobre a convivência com essas pessoas. A pesquisa sugere que esses leitores se deparam com as interações do protagonista com personagens pertencentes a grupos estigmatizados (elfos, meio gigantes, meio bruxos) e a partir disso podem ter desenvolvido uma perspectiva simpática a grupos discriminados, aplicando esse aprendizado também na perspectiva que têm sobre grupos desfavorecidos no contexto social em que vivem. "O livro literário com sua maleabilidade reflexiva pode causar um afrouxamento da rigidez estereotipada do pensamento, proporcionando novos modos de pensar e de existir, subvertendo o estado de coisas e provocando deste modo micro revoluções que podem se alastrar para toda a sociedade" (ALMEIDA, 2008, p.7). Nesse sentido, o que propomos com nosso objeto de estudo é também refletir sobre os valores culturais em torno de outra figura relegada à margem da sociedade: a mulher, neste caso, a partir da personagem feminina de maior protagonismo na série - a colega e melhor amiga de Harry, Hermione Granger. 
Em maio de 2011, a editora britânica dos livros da série Harry Potter, a Bloomsbury, lançou uma enquete para que os fãs escolhessem qual o seu personagem favorito da história de Rowling. O período de votação recebeu mais de 70 mil votos e teve como vencedor o professor Severo Snape 5 - com $20 \%$ dos votos -, e Hermione Granger conquistando o segundo lugar, na frente de personagens

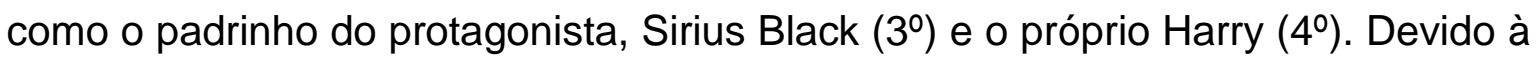
popularidade e ao protagonismo de Hermione na série, tida como a principal referência feminina para o leitor da obra, o objetivo desta pesquisa foi investigar quais as possíveis representações da personagem, observando como suas características, modos de agir e de se relacionar colaboram para moldar sua(s) identidade(s). Para isso, foram consideradas as tomadas de posição da própria personagem nos diálogos, do narrador ao descrevê-la e a forma com que outros personagens figuram a jovem bruxa, já que "as identidades flutuam no ar, algumas de nossa própria escolha, outras infladas e lançadas pelas pessoas em nossa volta" (BAUMAN, 2005, p. 19).

O conceito de identidade pós-moderna foi trazido à luz das teorizações de Stuart Hall (2001) e Zygmunt Bauman (2005), que explicam como ela é fluida, constituindo um processo em constante transformação. A constituição de personagens está ligada às identidades que elas apresentam, porém, sua fluidez e inconstância, de acordo com Antonio Candido (1968), tendem a ser um pouco menores do que as dos seres humanos reais, pelo fato de "viverem" em um universo um pouco mais limitado que o nosso - as páginas dos livros de seus enredos.

Os processos identitários das personagens são de suma importância para a identificação do leitor com as temáticas dos enredos, pois representam "a possibilidade de adesão afetiva e intelectual do leitor, pelos mecanismos de identificações, projeção, transferência, etc. A personagem vive o enredo e as ideias, e os torna vivos" (CANDIDO, 1968, p.54). Elas são os elementos literários que traduzem de maneira mais eficiente a nossa própria constituição de sujeitos, também em busca de uma identidade na tentativa de definir uma determinada

\footnotetext{
${ }^{5}$ Dados da reportagem do jornal britânico The Guardian, de agosto de 2011.
} 
posição na sociedade marcada pelas ideologias com as quais mais simpatizamos e procuramos perpetuar.

\section{Identidades flutuantes}

Quando conhecemos uma pessoa nova, nossa primeira forma de interação costuma ser a pergunta "quem é você?" e, então, o que vem automaticamente à mente para responder quase sempre tem relação com nossa função na sociedade capitalista, nossa profissão. Também é comum responder quem somos em relação à nossa posição dentro de grupos sociais a que pertencemos: família, comunidade escolar, igreja, grupo de amigos, etc. Manifestamos nossas identidades em diversos segmentos da sociedade, assumindo uma posição em cada um deles, nos tornando tão múltiplos que é difícil definir uma essência de um "quem sou eu" único. O conceito de identidade é muito complexo e nada conclusivo, principalmente, em decorrência das mudanças sociais que resultaram na modernidade líquida, termo utilizado por Zygmunt Bauman (2005) para designar a fase em que vivemos hoje na qual "o mundo em nossa volta está repartido em fragmentos mal coordenados, enquanto as nossas existências individuais são fatiadas numa sucessão de episódios fragilmente conectados" (p. 18). De acordo com Stuart Hall (2011) vivemos uma espécie de "crise de identidade" em que "as velhas identidades, que por tanto tempo estabilizaram o mundo social, estão em declínio, fazendo surgir novas identidades e fragmentando o indivíduo moderno, até aqui visto como um sujeito unificado" (p.7).

Aquela identidade linear estabelecida desde o nascimento e fixada até a morte do sujeito em estáveis tradições e estruturas já não funciona no mundo pósmoderno. Antigamente, poderíamos dizer que se uma pessoa nascia com um determinado status, geralmente pré-determinado pela classe social da família em que se encontrava, não tinha muita flexibilidade para mover-se tão além do degrau hierárquico herdado pela situação familiar. "Houve um tempo em que a identidade humana de uma pessoa era determinada fundamentalmente pelo papel produtivo desempenhado na divisão social do trabalho, quando o Estado garantia (se não na prática, ao menos nas intenções e promessas) a solidez e a durabilidade desse papel" (BAUMAN, 2005, p.51). Dessa forma, se a pessoa nascia de um pai que 
fosse ferreiro, ela provavelmente assumiria essa mesma carreira durante toda a sua vida.

A noção de sujeito começa a mudar na metade do século XX com a teoria da socialização, que propõe pensar o indivíduo de forma interativa e dialógica como formado subjetivamente através de sua participação nas relações sociais, mas também discute como esses papéis desempenhados por eles sustentavam as estruturas sociais. Portanto, a identidade desse sujeito sociológico é vista como “formada na 'interação' entre o 'eu' e a sociedade (...) formado e modificado num diálogo contínuo com os mundos culturais 'exteriores' e as identidades que estes mundos oferecem" (HALL, 2001, p. 11).

É graças à globalização que são comercializadas amplamente produções artísticas de diversos países estrangeiros, fazendo com que séries literárias como Harry Potter atinjam o alcance global, cativando milhões de fãs pelo mundo, que se identificaram de alguma forma com as representações propostas pelos enredos da obra. Hall (2004) explica que o sujeito pós-moderno é caracterizado por não possuir uma identidade fixa e permanente, pois "à medida em que os sistemas de significação e representação cultural se multiplicam, somos confrontados por uma multiplicidade desconcertante e cambiante de identidades possíveis, com cada uma das quais poderíamos nos identificar - ao menos temporariamente" (p. 13).

Além disso, o sujeito assume identidades diferentes para cada situação social diferente - a exemplo, a própria Hermione que pode ser representada da compaixão à frieza, dependendo do contexto em que está inserida. Atualmente experimentamos identidades diversas, às vezes até contraditórias, que disputam e nos empurram em diferentes direções. Essa transição de uma fase "sólida" para uma fase "líquida" da modernidade incide também sobre nossos processos identitários que acabam refletindo também a fluidez da sociedade, formando identidades voláteis que não conseguem "manter a forma por muito tempo e, ao menos que sejam derramados num recipiente apertado, continuam mudando de forma sob a influência até mesmo das menores forças" (BAUMAN, 2005, p.57).

A formação identitária é um processo comumente relacionado à infância e adolescência. Apesar de reunir fãs das mais variadas faixas etárias, podemos dizer que a obra Harry Potter traz várias características do gênero romance adolescente, como a presença de fantasia - de origem folclórica ou proveniente da adaptação de 
textos clássicos, como os contos de fada - e as intertextualidades apresentadas na composição dos enredos de J.K. Rowling. A literatura voltada ao público juvenil está ligada à formação identitária pelo fato de seus tradicionais leitores estarem em um período de transição da infância para a vida adulta, quando a liberdade de assumir uma personalidade autêntica começa a contornar os primeiros anseios de identidades futuras. As pesquisadoras Rosane Cardoso e Franciele F. Baccon (2015) discorrem algumas pressuposições sobre o leitor jovem e concluem que

\begin{abstract}
A literatura direcionada para adolescentes busca temáticas que possam responder questões que, de alguma forma, o perturbam. Será isso que provocará, possivelmente, a identificação com os personagens. Visando este público, as narrativas atuais - literárias e audiovisuais - constroem personagens de personalidade forte, mas com problemas e dúvidas que estão relacionadas com o crescimento pessoal, com a saída de casa, com o embate frente ao mundo adulto (p.93-4).
\end{abstract}

Isso é bem evidente logo no início da série fantasiosa quando, em Harry Potter e a Pedra Filosofal (2000), o protagonista descobre que é um bruxo. Podemos dizer que essa descoberta está relacionada à própria busca desse "quem sou eu". O romance para adolescentes geralmente representa o trajeto humano pela vida, mostrando que os personagens também precisam superar obstáculos, descobrir suas origens e potenciais para cumprir sua missão no mundo. $O$ fato de o enredo da série se desenrolar em um ambiente escolar faz com que essa relação com a vida humana promova ainda mais identificação por parte desse jovem público, pelo fato de representar-Ihes um espaço comum a sua rotina.

É nesses pontos em comum entre personagem e leitor que se torna evidente o processo de identificação dos sujeitos ao consumir-se uma obra. De acordo com Antonio Candido (1968), a personagem e o enredo exprimem em conjunto os objetivos, significados e valores que animam o romance (p.54). Assim como as identidades, as personagens também são abordadas da mesma "maneira fragmentária, insatisfatória, incompleta com que elaboramos o conhecimento dos nossos semelhantes" (CANDIDO, 1968, p.58). O principal fator que determina a incompletude descritiva em Harry Potter é a presença de um narrador-observador onipresente e onisciente apenas a Harry, ou seja, ele segue a linha dos fatos de acordo com as ações e pensamentos do protagonista; portanto, a representação de Hermione é também limitada pela maneira com que esse narrador a apresenta. 
Como explica Ferreira (2015), em um artigo que propõe uma análise da obra Harry Potter e a Pedra Filosofal (2000), "quando o narrador onisciente se sente impelido a avaliar moralmente os fatos, focaliza o protagonista e funde sua voz com os pensamentos deste, de maneira que é uma voz conjunta a que emite juízos de valor sobre as condutas humanas descritas" (p.125).

A identidade das personagens literárias é tão múltipla e fluida quanto a dos seres humanos reais. A diferença é que no real isso é imanente à nossa existência enquanto na obra essa visão é criada e

\begin{abstract}
racionalmente dirigida pelo escritor, que delimita e encerra, numa estrutura elaborada, a aventura sem fim, que é na vida, o conhecimento do outro. Daí a necessária simplificação, que pode consistir numa escolha de gestos, de frases, de objetos significativos, marcando a personagem para a identificação do leitor, sem com isso diminuir a dimensão de complexidade e riqueza (CANDIDO, 1968, p.58)
\end{abstract}

Abordar a identidade de gênero é essencial para compreender as representações da personagem Hermione, que em vários momentos fogem ao estereótipo feminino definido por uma cultura patriarcal também presente no universo bruxo. $O$ gênero é tão fluido quanto às identidades, pois sua

\begin{abstract}
totalidade é permanentemente protelada, jamais plenamente exibida em qualquer conjuntura considerada. Uma coalizão aberta, portanto, afirmaria identidades alternativamente instituídas e abandonadas, segundo as propostas em curso; tratar-se-á de uma assembleia que permita múltiplas convergências e divergências, sem obediência a um telos normativo e definidor (BUTLER, 2006, p.37)
\end{abstract}

\title{
Múltiplas Hermiones
}

A popularidade de Hermione entre o público de Harry Potter é tão grande que frequentemente J.K. Rowling é questionada a respeito do porquê de o protagonista ser do sexo masculino. A autora explicou em entrevista transcrita no artigo da pesquisadora Eliza Dresang (2002) que "Harry simplesmente 'brotou' inteiramente formado em sua mente e que o fato de ter desenvolvido uma Hermione tão indispensável para as aventuras da trama faz com que ela se sinta menos culpada de não ter colocado uma Harriet de vestido para protagonizar a série" (p.220, tradução nossa). O público da série também parece concordar com a 
essencialidade da personagem: na internet circulam imagens de fãs segurando cartazes com os dizeres "Sem Hermione Harry teria morrido no primeiro livro". As características mais corriqueiramente relacionadas à personagem são inteligência, determinação, amizade e coragem. A garota faz da leitura e do conhecimento os seus principais aliados para o seu aperfeiçoamento em magia.

A escritora da série costuma destacar a importância da escolha dos nomes de seus personagens. Entre Harry, Rony e Hermione, a menina é a que tem o nome mais incomum, chamando nossa atenção. Pela etimologia, verificamos uma derivação do nome Hermes, deus grego que possui diversos atributos, dentre eles a divindade da magia. Ao passo que adentramos no universo mágico proposto por Rowling através da leitura da obra, percebemos que a autora faz referências tanto mitológicas, quanto históricas e literárias na criação de seus enredos, como quando nomeia as personalidades bruxas famosas cujas imagens estão impressas nas embalagens de um doce que Harry compra durante a viagem até a escola de magia: "Logo não tinha só Dumbledore e Morgana, como também Hengisto de Woodcroft, Alberico Grunnion, Circe, Paracelso e Merlin" (ROWLING, 2000, p.92). O primeiro, terceiro e quarto nomes são personagens de criação original da autora, enquanto Morgana e Merlin são magos rivais das tradicionais lendas medievais sobre o Rei Arthur, Circe é uma feiticeira maligna da mitologia grega - conhecida também pelo episódio com Ulisses, na Odisseia (VIII a.C.), de Homero - e Paracelso, um médico, alquimista suíço-alemão que desenvolveu trabalhos sobre o zinco no século XVI.

$\mathrm{Na}$ investigação mais aprofundada das referências que a autora poderia ter feito ao batizar Hermione, constatamos que esse nome carrega uma herança significativa da tradição mitológico-literária. Segundo Dresang (2002), na mitologia grega Hermione é a filha de Helena de Troia e Menelau, rei de Esparta. No contexto mitológico, a mãe abandona a família e foge para viver um romance com o príncipe Paris, também de Troia como ela. A princesa Hermione, portanto, tem uma infância conturbada pelo abandono da mãe e pelas ausências do pai que viaja constantemente para guerras de conquista e defesa de territórios. Quando adulta, é prometida primeiro a Orestes e depois a Neoptólemo, mas acaba casando-se com este último. A figura de Hermione aparece na tragédia Andrômaca (425 a.C.), de Eurípedes, na qual sua personagem segue a linearidade mitológica e se ocupa 
com planos de vingança ao marido Neoptólemo, pelo fato de este ter tomado Andrômaca como amante, uma mulher

\begin{abstract}
Trazida para a Ftia por Neoptólemo, após a queda de Tróia, vê-se constrangida a ser concubina deste e dá à luz um filho, Molossos, pelo que é hostilizada pela ciumenta Hermíone, a estéril filha de Menelau, com quem Neoptólemo casara. Aproveitando a ausência do marido, a filha de Helena prepara a morte da Troiana e do filho. Salva-os a intervenção do velho rei Peleu, pai de Aquiles e avô de Neoptólemo (FERREIRA, 1972, p. 452)
\end{abstract}

As tentativas de vingança de Hermione para com seu marido fracassam, então ela decide fugir e viver com Orestes, que mais tarde assassina o próprio Neoptólemo, por este ter inicialmente lhe roubado sua prometida esposa. O casal então vive por muitos anos como monarcas de Esparta, Micenas e Épiro, territórios conquistados por Orestes. A Hermione de Eurípides é representada como uma mulher que utiliza o intelecto e a determinação para alcançar seus objetivos, algumas características deixadas de herança à personagem de Rowling, que também manifesta claramente esses traços. O ciúme e o desejo de vingança também aparecem na Hermione de Harry Potter, porém não como características ligadas entre si e também não tão intensificadas a ponto de provocarem atitudes homicidas, como em Andrômaca.

A manifestação literária de Hermione ainda se perpetua ao longo dos séculos com a aparição do nome nos Contos de Inverno, de Shakespeare (1611), que batiza a esposa do rei Leonte, que no contexto da obra manda prendê-la devido aos ciúmes da relação dela com o amigo Polixeno, rei de Bohemia. Enclausurada e grávida da filha Perdita, Hermione forja a própria morte e entrega a criança aos cuidados de uma família da comunidade. Anos mais tarde, o rei Leonte reencontra a filha perdida e logo Hermione reaparece revelando que ainda estava viva. A família se reconcilia e celebra o casamento de Perdita com o filho de Polixeno, este que também teve a amizade restituída com Leontes após a volta das mulheres ao reino. Novamente o nome é designado a uma personagem marcada pela determinação em busca de seus objetivos - afinal aguarda anos para concretizálos. Somando-se a essa qualidade também notamos o desejo de fazer justiça, no caso da obra de Shakespeare, em benefício próprio diante da sua injusta prisão 
ordenada pelo marido, enquanto a personagem de Rowling luta mais incisivamente pelos direitos de outros personagens em situação vulnerável.

Finalizando a trajetória literária do nome, temos Hermiones em mais dois romances relacionados entre si: Mulheres apaixonadas, do britânico D.H. Lawrence (1920) e HERmione, da estadunidense Hilda Doolittle (1981). Segundo Dresang (2002), Hilda esteve em uma estreita relação com Lawrence entre os anos de 1914 e 1918. O enredo de seu famoso romance de 1920 - dois anos após o período de proximidade com Doolittle - inclui uma das protagonistas chamada Hermione, que representa uma mulher em busca de compreensão e controle intelectual sobre seu ambiente. Já o romance de Hilda é uma autobiografia escrita em 1927, mas publicada somente cinquenta e quatro anos depois por sua filha Perdita - que possui o mesmo nome da filha de Hermione dos Contos de Inverno.

As Hermiones dessa tradição literária conduzida principalmente pelo cânone ocidental possuem um ponto em comum - "têm as vidas controladas por homens ao seu redor, ainda que elas sejam mulheres fortes que usam a sua inteligência e posição social para procurar seu destino no mundo" (DRESANG, 2002, p.216, tradução nossa). Esses traços também se manifestam na Hermione de Rowling, afinal "todas as obras literárias, em outras palavras, são 'reescritas', mesmo que inconscientemente pelas sociedades que as leem" (EAGLETON, 2006, p.18). A Hermione bruxa também age no contexto em que está inserida utilizando o saber como principal ferramenta para conquistar seu lugar no mundo mágico. Os textos literários caracterizam-se por esse diálogo com os textos clássicos da tradição, propondo não uma cópia, mas uma emulação destes, conceito que pode ser entendido como

um esforço que leva o imitador a igualar, se não a ultrapassar, o próprio modelo, definição corroborada por Quintiliano, segundo o qual "só pela imitação não há crescimento", pois "também serão celebrados aqueles que forem considerados como tendo superado os seus antecessores e ensinado os seus sucessores". Pode-se perceber, então, que no conceito de emulação encontram-se as noções de rivalidade e superação. O sentimento da emulação desperta no artista um desejo de "rivalizar com o que parece haver de melhor em cada um dos antigos" e de "superar as particularidades dessas obras”. (SALTARELLI, 2009, p. 254-5)

A pluralidade identitária de uma personagem, tal como constatamos em Hermione, é um dos reflexos também desse desejo de superação que move a 
criatividade dos escritores em direção a uma composição de personagens cada vez mais complexa.

Em Harry Potter e a Pedra Filosofal (2000), Hermione aparece na trama ainda no trem em que viaja à escola de magia, quando encontra Harry e o também calouro Rony Weasley em uma das cabines. Na primeira conversa com os garotos, ela já revela a principal característica pela qual é costumeiramente associada ao longo da série - a intensa dedicação aos estudos, pois já lera diversos livros sobre magia antes mesmo de colocar os pés em Hogwarts. Ainda na conversa com os garotos no trem, Hermione revela ter descendência de família "trouxa". A característica parece ser um dos pontos que mais impulsionam sua compulsão pelos estudos - para compensar todos os anos sem saber da existência do universo mágico, a garota devora referências bibliográficas.

Mesmo já possuindo algum conhecimento sobre o mundo mágico, a personagem deixa transparecer uma sutil descrença pessoal em torno do questionamento se estaria de fato suficientemente preparada para a escola, afinal mais tarde eles passariam pelo processo de seleção para alguma das quatro casas de Hogwarts, episódio no qual "ninguém falava muito a não ser Hermione, que cochichava muito depressa todos os feitiços que aprendera, sem saber o que precisaria mostrar" (ROWLING, 2000, p.102). A ansiedade em provar sua competência acompanha a personagem em todas as aulas da escola de magia. Além disso, a garota também demonstra uma destreza em magia logo nas primeiras aulas, em que, geralmente, é a primeira aluna a produzir de maneira eficaz os feitiços propostos em classe.

Dresang (2002) sugere que "a compulsividade pelos estudos demonstrada em Hermione de início ajuda a desenvolver uma personagem forte no futuro" (p.222, tradução nossa), apesar deste incisivo traço em sua personalidade ter causado certo incômodo nas primeiras impressões dos colegas ainda na viagem de trem à Hogwarts - "Seja qual for a minha casa, espero que ela não esteja lá", comenta Rony (ROWLING, 2000, p.95). Harry, Rony e Hermione acabam sendo selecionados para a mesma casa de Hogwarts mais tarde - a Grifinória - e tendo que conviver juntos. A proximidade faz com que os meninos confirmem sua inimizade com a garota após ela reprimir algumas atitudes deles que infringiriam o regulamento escolar, como sair dos dormitórios e andar pela escola à noite. 
Em uma das aulas de Feitiços, os alunos são divididos em duplas. Rony, que teria que trabalhar com Hermione, fica incomodado com os comentários corretivos da garota em relação à maneira errônea com que ele tentava produzir o encantamento proposto pelo professor. Para extravasar esse sentimento, mais tarde o garoto se refere à menina como "um pesadelo" em uma conversa com os amigos e, apesar de Hermione não estar nesse círculo, ela esbarra em Rony ao passar e os meninos desconfiam que ela possa ter ouvido o julgamento que fizeram dela. A menina não aparece nas aulas seguintes e, durante o jantar, os meninos ficam sabendo que ela passou o dia todo chorando no banheiro feminino. A essa altura do enredo, a sensibilidade da personagem funciona como um fio condutor para o episódio seguinte.

À noite, um trasgo invade o castelo de Hogwarts, Harry e Rony correm para avisar Hermione, quando descobrem que o monstro está indo justamente em direção aos banheiros em que ela se encontrava. Os colegas a salvam do ataque do trasgo, usando magia para deixar a criatura inconsciente no chão do banheiro. Uma das professoras de Hogwarts chega ao local, desaprova a bagunça e o desrespeito dos alunos ao toque de recolher dado quando a direção da escola ficou sabendo da entrada do trasgo. Antes de a professora dirigir o sermão, Hermione defende os garotos e assume a culpa por estarem fora de seus aposentos, evitando que Harry e Rony sejam punidos pela situação. A atitude deixa os garotos surpresos já que "Hermione era a última pessoa do mundo que desobedeceria ao regulamento, e ali estava fingindo que desobedecera, para tirá-los de uma enrascada" (ROWLING, p.155).

Os três fazem as pazes e tornam-se amigos. A proximidade de Hermione com Harry e Rony revela uma relação além da amizade, pois ela começa a agir de uma forma um tanto maternal com os garotos, quando passa a organizar as tarefas diárias deles. A colega fiscaliza os deveres de casa dos amigos e até define cronogramas para eles com as revisões de conteúdo antes das provas.

Ao longo da aventura em Harry Potter e a Pedra Filosofal o trio acaba entrando ocasionalmente em uma sala proibida para os alunos, na qual encontram um cão de três cabeças como guarda de um alçapão. Os amigos desconfiam que a passagem abre caminho a algo muito misterioso, valioso e cobiçado, considerando a mortífera medida de proteção do local com a qual se depararam. A 
partir de algumas pistas e de intensas pesquisas na biblioteca, Hermione chega à resposta sobre o misterioso objeto guardado e descobre que é a pedra filosofal. Os amigos começam a desconfiar que um dos professores de Hogwarts está com a intenção de roubá-la para usufruir de uma de suas propriedades - "o Elixir da Vida, que torna quem o bebe imortal" (ROWLING, 2000, p.190). Os três, portanto, decidem sair em busca da pedra antes que ela seja roubada e, para isso, precisam passar por uma série de encantamentos que protegem o objeto.

O primeiro desafio é passar pelo enorme cão de três cabeças que só se acalma quando ouve música, porém quando o trio chega à sala encontra uma harpa encantada que já fazia o animal dormir com seu som, indicando que algum outro bruxo já estava à frente na corrida pela pedra. Rony usa suas estratégias para vencer o próximo desafio de uma partida de xadrez de bruxo, Harry usa suas habilidades de voo para capturar uma chave voadora que abre uma das portas e Hermione evita com um feitiço que os amigos sejam esmagados por uma planta chamada "visgo-do-diabo", que mata por asfixia qualquer ser vivo que se aproxima. Ainda no trajeto até a pedra, os amigos se deparam com um enigma em que é preciso escolher duas entre sete poções a serem bebidas sem que haja o equívoco de acabarem tomando as venenosas. A garota utiliza seu raciocínio lógico para a resolução do enigma e chega corretamente à conclusão.

A autora confirma a relevância da personagem para a trama ao colocá-la como a figura essencial na superação de alguns desafios cruciais na jornada do herói Harry, afinal "sem Hermione Harry teria morrido no primeiro livro", pois as chances de o menino ter escolhido o frasco de poção errado seriam maiores sem a amiga por perto.

\section{Menininha boba, é?6}

Inteligente e corajosa. Brava e sarcástica. Sensível e cuidadosa. Constatamos que são inúmeras as características de Hermione que se conectam em várias direções, formando cruzamentos, que se encontram para compor novas

\footnotetext{
6 Hermione é adjetivada dessa forma pela jornalista Rita Skeeter, em Harry Potter e o Cálice de Fogo (2001), ao confrontá-la sobre a forma antiética com que trata as pessoas em suas reportagens. A garota prova que Rita estava errada ao caracterizá-la como "boba", pois ela consegue ser mais esperta que a comunicadora e desmascara sua identidade secreta.
}

Revista de Letras JUÇARA, Caxias - Maranhão, v. 03, n. 01, p. 122 - 141, ago. 2019 | 136 
intersecções. Essas ligações de todos os lados formam a teia identitária da personagem, frágeis linhas que podem ser desfeitas sob qualquer interferência do ambiente, mas que também são passíveis de reconstrução, mesmo que esse contínuo trabalho de formação identitária ganhe diferentes modelos a cada tecer. Apesar da fragilidade dessa constituição, a repetição de linhas que seguem o mesmo fluxo pode se conjugar e formar cerdas mais grossas, dando contornos um pouco mais definidos para a teia da personalidade. Assim, sugerimos que Hermione possui três dessas cerdas mais resistentes, representadas por sua "sabedoria performativa", "subversão de gênero" e "razão e sensibilidade"7.

A fantasia oferece um material maleável para a ordenação interpretativa na mente do leitor. Os caminhos são diversos até a integração do sentido de obras de fiç̧ão e não podemos afirmar uma ou outra tendência para o trabalho da imaginação. Como as identidades, ela também é múltipla, afinal ainda estamos no campo da consciência do sujeito. O que é certo diante desse percurso é que a literatura fantástica tem a magia de preencher lacunas no trilhar da compreensão mundana. Histórias fantasiosas do caráter da série Harry Potter permitem que o leitor se projete nelas, através do processo de identificação, como sugeriu Antonio Candido (1968), para visualizar performances alternativas de personagens, que buscam, assim como todo ser humano, libertar-se de barreiras que possam estar obstruindo o caminho de sua evolução pessoal.

Vale lembrar que a identidade, como discutimos a partir de Stuart Hall (2011) e Zygmunt Bauman (2005), é constituída em um diálogo entre o sujeito e as representações diretas com as quais temos contato na vida social - mãe, pai, familiares, amigos -, mas também a partir de representações indiretas, que são simbolizadas através de produções culturais, como a literatura, música, televisão e cinema. Com intertextos vindos de todos os lados, a obra Harry Potter possui uma densa bagagem ideológica, desconstruindo o estigma de simplicidade que uma vez era usado para qualificar a literatura voltada ao público infantil e juvenil.

Concluímos que as histórias do gênero maravilhoso, como os contos de fadas e a série objeto dessa pesquisa, "expressam conteúdos ligados à psique,

\footnotetext{
7 Esses três blocos temáticos são explorados de forma mais abrangente pelas autoras na dissertação de Mestrado que embasou este artigo, intitulada ldentidades flutuantes de Hermione: representações de gênero na constituição da personagem da série Harry Potter (2019).
}

Revista de Letras JUÇARA, Caxias - Maranhão, v. 03, n. 01, p. 122 - 141, ago. 2019| 137 
marcas do mais profundo inconsciente humano, evidenciando problemáticas que atravessam todos os tempos. Um conto de fadas enseja ações muito mais complexas que apenas ouvir ou ler, remetendo o receptor a travessias cujo valor só ele pode alcançar" (MICHELLI, 2015, p.51). A partir dessa reflexão podemos vislumbrar a importância do processo de identificação entre leitor e personagens, pois essa relação colabora para moldar formas de pensar e agir, afinal, quem nunca se inspirou com alguma figura literária ou cinematográfica que fosse o modelo exato do que gostaríamos de ser?

Pelo fato de a série ter um grande público infantil, é também grande a responsabilidade sobre as representações que constrói ao longo das narrativas. Nesse sentido, devem ser tratadas com cautela também as relações de gênero presentes nessas histórias, visto que a identidade de gênero começa a se organizar ainda na infância e, portanto, a criança e o adolescente podem ser altamente influenciados pelas simbologias atribuídas aos personagens. Concluímos que Rowling não escreve seus romances priorizando ideais feministas, afinal o foco dos enredos não é discutir nem incutir igualdade de gênero. Mesmo assim,

\footnotetext{
sua insistência em outras questões éticas, bem como as tentativas de vários personagens para combater a desigualdade e o racismo, parecem estar em conformidade com as posições das teorias feministas modernas, que enfatizam a inclusão e se preocupam com todas as formas de repressão e marginalização, não apenas a repressão e marginalização das mulheres (MIKULAN, 2009, p.294, tradução nossa)
}

Rowling criou uma Hermione que vive em um contexto onde a diferenciação sexual - além de outras discriminações, como a direcionada às criaturas não humanas - está presente e funciona como um dos critérios para a distribuição dos poderes. No entanto, a autora nos apresenta uma personagem subversiva dentro desse universo, pois ela resiste às matrizes culturais criadoras dos estereótipos definidores de sexos/gêneros. A partir da performatividade de gênero de Hermione concluímos que a personagem é representada na bifurcação de traços femininos e masculinos, desconstruindo alguns estereótipos de gênero que por tanto tempo regeram as histórias infantis. Ao invés do tradicional papel feminino de companheira afetiva do herói, ela é amiga e companheira de batalhas do protagonista. Dessa forma, percebemos que algumas dessas linhas representativas que formam a teia 
identitária de Hermione têm alguns traços feministas, corroborando com a proposta de identidades cada vez mais múltiplas e transformáveis no contexto pósmodernista em que vivemos.

É importante lembrar que, parafraseando Butler (1998, p.22), a identidade de um sujeito nunca está plenamente acabada, mas é produzida continuamente, possibilitando ressignificações ao longo dessa construção. Este é o caso de Hermione, cuja repetição estilizada de atos foi catalogada neste trabalho, na tentativa de propor alguns dos efeitos substantivos que a personagem representa, mas sem tomá-los como definitivos, já que a fluidez da identidade e da interpretação não permitem que a coloquemos em uma caixinha - as características podem deslizar para fora através das frestas a qualquer movimento.

Lembremo-nos sempre que não é possível definir uma identidade una para o termo "mulher", pois não podemos pressupor características comuns ou específicas do gênero feminino, mas podemos investigar de que forma é elaborada a complexa teia identitária de cada uma das "mulheres", no plural, e de que forma essa heterogeneidade reconfigura novas e maleáveis performances de feminilidade, como as que fortalecem Hermione como uma heroína tão essencial quanto o protagonista na série Harry Potter.

\section{HERMIONE'S IDENTITY MULTIPLICITIES IN THE HARRY POTTER SERIES}

Abstract: Hermione Granger is a classmate and friend of the protagonist of the Harry Potter series. Intelligence is its main feature and instrument of combat against the Dark Arts, staying with the hero of the saga in this task until the end of the adventure. The relevance of the character to the plot is noticed in surveys that evaluate the favoritism of fans of the series, who seem to identify with Hermione. This work is a cut from a Master's dissertation that investigated the possible representations of the female character of greater prominence in the Harry Potter series. The theoretical basis of Literary, Cultural and Gender Studies has led to an understanding of how the relations between power and sexual differentiation in witch society works. Hermione's subversive identity deconstructs some cultural matrices and urges us to reflect on the gender stereotypes that have so long marked the literature aimed at children and young people.

Keywords: Identity. Children's literature. Gender.

\section{Referências}

ALMEIDA, Leonardo Pinto. Leitura e subjetividade: reflexões sobre a linguagem e o exercício da liberdade. In: Encontro de Estudos Multidisciplinares em Cultura (IV Enecult), Faculdade de Comunicação/UFBa, Salvador, Bahia. Disponível em: http://www.cult.ufba.br/enecult2008/14418.pdf . Acesso em 10 de julho de 2017. 
BAUMAN, Zygmunt. Identidade. Tradução: Carlos Alberto Medeiros. Rio de Janeiro: Jorge Zahar Ed., 2005.

BUTLER. Judith. Fundamentos contingentes: o Feminismo e a questão do "Pósmodernismo". In: Cadernos Pagu. Vol. 11, 1998, p.11- 42.

BUTLER, Judith. Problemas de gênero: feminismo e subversão da identidade. Trad. Renato Aguiar. Rio de Janeiro: Civilização Brasileira, 2006.

CANDIDO, Antonio. O direito à literatura. In: Vários escritos. 5a ed., São Paulo: Duas Cidades, 2011 p. 171-193.

. A personagem no romance. In: CANDIDO, Antonio; GOMES, Paulo Emílio Salles; PRADO, Décio de Almeida e ROSENFELD, Anatol. A Personagem de Ficção. São Paulo: Perspectiva, 1968.

CARDOSO, Rosane; BACCON, Franciele F. Os contos de fadas em narrativas contemporâneas: pressuposições sobre o leitor jovem. In: DEBUS, Eliane Debus; MICHELLI, Regina (orgs). Entre fadas e bruxas - o mundo feérico dos contos de fadas para crianças e jovens. Rio de Janeiro: Dialogarts, 2015.

DRESANG, Eliza T. Hermione Granger and the Heritage of Gender. In: Whited, Lana A. (org.). The Ivory Tower and Harry Potter: Perspectives on a Literary Phenomenon. Columbia/London: University of Missouri Press, 2002, 211-242. Disponível em:

em https://harrypottersummer2011.files.wordpress.com/2011/05/hermione-grangerand-the-heritage-of-gender.pdf . Acesso em 15 de outubro de 2017.

EAGLETON, Terry. Teoria da Literatura: uma introdução. São Paulo: Martins Fontes, 2006.

FERREIRA, Eliane Aparecida Galvão Ribeiro. Uma Cinderela moderna e seus encantamentos: análise da obra Harry Potter e a Pedra Filosofal, de J.K. Rowling. In: DEBUS, Eliane Debus; MICHELLI, Regina (orgs). Entre fadas e bruxas - o mundo feérico dos contos de fadas para crianças e jovens. Rio de Janeiro: Dialogarts, 2015.

FERREIRA, J. Ribeiro. A figura de Andrômaca. Portugal: Associação Portuguesa de Estudos Clássicos, 1972. Disponível em https://www.uc.pt/fluc/eclassicos/publicacoes/ficheiros/humanitas23-

24/05_JRF.pdf . Acesso em 12 de novembro de 2017.

HALL, Stuart. "Quem precisa da identidade?". In: SILVA, Tomás Tadeu das Silva (org.). Identidade e diferença: a perspectiva dos estudos culturais. Petrópolis: Vozes, 2000, pp. 103-133.

HALL, Stuart. A identidade cultural na pós-modernidade. Trad. Tomaz Tadeu da Silva. Rio de Janeiro, RJ: DP\&A Editora, 2011. 
MICHELLI, Regina. O herói (des)prestigiado nos contos de Grimm: a personagem masculina do tolo. In: ZINANI, Cecil J.A; CARVALHO, Diógenes B.A. Estudos de gênero e literatura para crianças e jovens: um diálogo pertinente. Caxias do Sul, RS: Educs, 2015.

MIKULAN, Krunoslav. Harry Potter through the Focus of Feminist Literary Theory: Examples of (Un)Founded Criticism. In: The Journal of International Social Research, Vol. 2, n. 9, 2009.

ROWLING, Joanne Kathleen. Harry Potter e a Pedra Filosofal. Rio de Janeiro: Rocco, 2000a, 263p. . Harry Potter e o Cálice de Fogo. Rio de Janeiro: Rocco, 2001, 583p.

SALTARELLI, Thiago. Imitação, emulação, modelos e glosas: o paradigma da mímesis na literatura dos séculos XVI, XVII e XVIII. In: Revista Aletria. Belo Horizonte, no especial, jul. - dez. 2009, p. 251 - 264. Disponível em http://www.periodicos.letras.ufmg.br/index.php/aletria/article/viewFile/1517/1613. Acesso em 13 de setembro de 2018.

THE GUARDIAN. Snape is voted favourite Harry Potter character. 2011. Disponível em: https://www.theguardian.com/childrens-books-site/2011/aug/30/snapefavourite-harry-potter-character . Acesso em 25 de maio de 2017.

TODOROV, Tzvetan. Introdução à literatura fantástica. Tradução de M. Clara C. Castello. São Paulo: Perspectiva, 1998, 96p.

VEZZALI, Loris; STATHI, Sofia; GIOVANNINI, Dino; CAPOZZA, Dora; TRIFILETTI, Elena. The greatest magic of Harry Potter: Reducing prejudice. In: Journey of Applied Social Psicology. Vol. 45, 2ª ed, fev. 2015, p.105-121. Disponível em: https://onlinelibrary.wiley.com/doi/epdf/10.1111/jasp.12279. Acesso em 12 de novembro de 2017.

Data da Submissão: 26/01/2019

Data da Aprovação: 04/06/2019 